\title{
樹皮に沈着した重金属污染モニタリングのための合成樹脂 接着剤を用いる新しいサンプリング法の開発
}

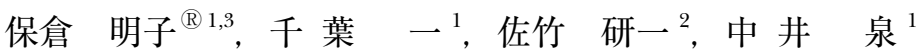

\begin{abstract}
環境污染評価のための広域・高密度なモニタリング法として，合成樹脂接着剤を用いる樹皮に沈着した重 金属污染物質のサンプリング手法の開発を行った．樹木（ケヤキ）の地上から約 $160 \mathrm{~cm}$ の高さの外樹皮表 面に, セメダインハイスーパー 5 を塗布し, 硬化後に剥離して, 誘導結合プラズマ質量分析装置で分析を行 った， $\mathrm{V}, \mathrm{Zn}, \mathrm{Cd}, \mathrm{Sb}, \mathrm{W}, \mathrm{Pb}$ は接着剤により効率的に回収でき，環境污染評価に使えることが分かった． この接着剤剥離法により，都市域，郊外，森林地域を含む 6 地点に扔ける環境污染評価を行ったところ，都 市域に扔ける $\mathrm{V}, \mathrm{Cu}, \mathrm{Zn}, \mathrm{Cd}, \mathrm{Sb}, \mathrm{W}, \mathrm{Pb}$ の濃度（例： $\mathrm{Pb} 1920 \mathrm{ng} \mathrm{cm}^{-2}$ ) は, 森林地域に打ける濃度（例： $\left.\mathrm{Pb} 153 \mathrm{ng} \mathrm{cm}^{-2}\right)$ の約 10 倍高く，それぞれの地点における污染の特色を得ることができた. 本手法は迅速・ 簡便で樹木へ与えるダメージが少ない採取法であることから，今後は様々な地域における污染評価へ適用す ることが期待される.
\end{abstract}

\section{1 はじめに}

現在，様々な人間活動により多種の污染物質が放出され ており, その污染状沉を把握するため, 都道府県等では, 大気の污染状況の常時監視を行っている. 大気中の污染物 質は自動測定機により測定されており，全国で 24 時間に わたり分析值が収集されているものの，分析装置を常設し なければいけないため, 決められた場所でしか測定できな いというデメリットがある。

一方，植物を使用することにより，迅速・簡便に様々な 場所に抢ける大気污染の状態を把握しょうとする研究が古 くから数多くなされている ${ }^{1) \sim 5)}$. また，植物の中でも樹木 の外樹皮は大気污染物質, 特に重金属を蓄積することが分 かり，外樹皮を大気污染物質のバイオモニターとして用い る環境污染評価 $\left.{ }^{6} \sim 12\right)$ が多く行われるようになってきた。

Bellis らは，英国のダービーシャー州にある鉛製錬所の 近くの外樹皮中の鉛濃度が $100 \sim 25000 \mathrm{mg} / \mathrm{kg}$ と高濃度で あることを報告している6 . また近年, 茨城県東海村で起 きた臨界事故後に採取された外樹皮に含まれるウランの同 位体比を分析したところ, 天然のウランの同位体比 ${ }^{235} \mathrm{U} /{ }^{238} \mathrm{U}=0.0072$ に対して, 外樹皮試料では ${ }^{235} \mathrm{U} /{ }^{238} \mathrm{U}=$ $0.00697 \sim 0.01448$ とウランの放射性同位体 ${ }^{235} \mathrm{U}$ の同位体 比が高くなっており，放射性物質が環境中へ放出されてい

\footnotetext{
${ }^{1}$ 東京理科大学理学部応用化学科：162-8601 東京都新宿区神楽 坂 1-3

2 立正大学地球環境科学部 : 360-0194 埼玉県熊谷市万吉 1700

3 現在所属 早稲田大学高等研究所 : $169-8050$ 東京都新宿区西 早稲田 1-6-1
}

ることを示した ${ }^{7)}$. 更に, Becker らは，高速道路や工業地 帯の外樹皮の Pt 濃度が $0.07 \sim 5.4 \mathrm{ng} \mathrm{g}^{-1}$ であり，これは自 動車の排出ガスを抑制するための触媒から，白金族元素の 微粒子が放出されているためであると報告している ${ }^{8)}$ 。ま た，イタリアカサマッ (Pinus pinea L.) の外樹皮と木部に おける $\mathrm{Al}, \mathrm{Ba}, \mathrm{Cr}, \mathrm{Cu}, \mathrm{Fe}, \mathrm{Pb}$ の濃度を調べた研究から

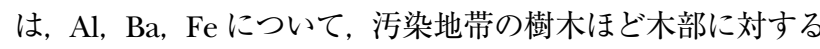
外樹皮中の元素濃度が高いとされている ${ }^{11)}$. Schelle らは, イギリス・Sheffieldにある 642 本の樹木の外樹皮中元素濃 度を調べて, 都市に扔ける元素マッピングを作成し，元素 発生源の特定に有効であると報告している ${ }^{12)}$ 。このよう に，樹木は様々な場所に分布しており，一定の場所で長期 間生育することから，その生育地域の大気環境污染を評価 するための適切な試料であるといえる。しかし，このよう な従来の樹皮を用いた環境污染モニタリングの研究 ${ }^{(6) \sim 12)}$ では，樹木から外樹皮そのものを採取するため，樹木に傷 を付けてしまうという問題点があった．また，一般的に国 道などの沿道や公園などに植えられている樹木の多くは公 共のものであるため, 公共の樹木に傷を付ける手法では許 可を得ることが難しく，限られたサンプリングしか行えな いという問題もある。

そこで本研究では, 污染物質が樹木の外樹皮の表面に沈 着することに着目し, 樹木の外樹皮最表層部の採取が行え る新しいサンプリング方法として，合成樹脂（接着剂）を 樹木の外樹皮に塗布し，それを剥離・回収する採取法とそ の分析手法の開発を目的とした．また，この接着剤を使っ た剥離法により，幾つかの地域での調查を行い，本手法の 
Table 1 Measurement conditions for ICP-MS

\begin{tabular}{ll}
\hline Plasma conditions & \\
RF frequency & $27.12 \mathrm{MHz}$ \\
RF power & $1500 \mathrm{~W}$ \\
Makeup gas & $0.30 \mathrm{~L} \mathrm{~min}^{-1}$ \\
Carrier gas & $1.25 \mathrm{~L} \mathrm{~min}^{-1}$ \\
Sampling conditions & \\
Sampling depth & $4.0 \mathrm{~mm}$ \\
Sampling cone & $\mathrm{Ni}, 1.0 \mathrm{~mm}$ orifice diameter \\
Skimmer cone & $\mathrm{Ni}, 0.4 \mathrm{~mm}$ orifice diameter \\
Nebulizer & $\mathrm{Babington}$ \\
Spray chamber temperature & $2^{\circ} \mathrm{C}$ \\
Sample uptake rate & $0.1 \mathrm{rps}$ \\
Data acquisition & \\
Data point & 3 points/peak \\
Integration time & $1.0 \mathrm{~s} /$ point \\
Repetition & 3 times \\
\hline
\end{tabular}

有用性を実証したので報告する.

$$
2 \text { 実験 }
$$

\section{$2 \cdot 1$ 分析装置}

微量成分元素の分析には, 誘導結合プラズマ質量分析装 置（ICP-MS，Agilent Technologies 製 Agilent7500c）を用 いた. 測定条件を Table 1 に示した. これらの測定条件は, 測定感度に影響するパラメーターについて最適化を行って 求めたものである.

ICP-MS 測定では, 内標準元素 Ge, In, Re を用いて内標 準補正を行った ${ }^{13)}$ 。また, ${ }^{27} \mathrm{Al},{ }^{51} \mathrm{~V},{ }^{75} \mathrm{As},{ }^{85} \mathrm{Rb},{ }^{88} \mathrm{Sr}$ に対 する多原子イオン $\left({ }^{26} \mathrm{Mg}^{1} \mathrm{H},{ }^{35} \mathrm{Cl}^{16} \mathrm{O},{ }^{40} \mathrm{Ar}{ }^{35} \mathrm{Cl},{ }^{48} \mathrm{Ti}{ }^{37} \mathrm{Cl}\right.$, ${ }^{48} \mathrm{Ti}^{40} \mathrm{Ar}$ ) の干渉補正係数を求め, 多原子イオン干渉の補正 を行った。

\section{$2 \cdot 2$ 試 薬}

試料溶液の調製及び希釈には，すべて日本ミリポア製超 純水製造システム $\left(\right.$ Direct- $\left.Q^{\mathrm{TM}}\right)$ で製造した超純水を用い た，試料の分解には，関東化学製高純度電子工業用（EL） 硝酸及び和光純薬製の原子吸光分析用過酸化水素, 和光純 薬製特級フッ化水素酸を使用したＩCP-MS 測定における 検量線溶液は, 和光純薬製の原子吸光分析用単元素標準溶 液（1000 $\mathrm{mg} \mathrm{kg}^{-1} ）$ を適宜混合希釈して調製した，混合検 量線溶液は, 溶液の安定性, 多原子イオン干渉等の誤差の 原因を避けるように考慮して使用した。

\section{$2 \cdot 3$ 接着剤試料}

樹木に塗布する接着剤として最適なものを選択するた め, 市販の接着剤 24 種を購入して検討した。接着剤には, 合成樹脂やゴムなどの高分子が水や有機溶媒に溶けた液体 状の水性接着剂や溶剂型接着剂, 合成樹脂を水に乳化分散 させたエマルジョン型接着剤, 2 液を混合させ化学反応に
よって硬化する反応型接着郕などの種類がある ${ }^{14)}$. 今回 は, 市販の水溶性接着剂 1 種, 溶㣂型接着剂 9 種, エマル ジョン型接着剂 2 種, 化学反応型接着剂 12 種の計 24 種を 用いた。

樹皮に沈着した污染物質を剥離・回収するための接着剤 としては，(1) 硬化した後に剥離しやすいこと，(2) 硬化が 迅速であること, (3) 不純物の含有量が低いことが望まし い，そこでまず，すべての接着剤試料を外樹皮表面に塗布 し，それを剥離させたときの，剥離しやすさ，硬化の迅速 性について検討した，更に接着剤の不純物の含有量を明ら かにするため，接着剤をポリテトラフルオロエチレン （PTFE）シートに塗布して剥離・回収した試料を作製し， 酸分解後に ICP-MS で分析を行った.

\section{$2 \cdot 4$ 試料の酸分解}

ICP-MS による分析を行う場合には，基本的に溶液試料 が対象となるので, 試料の分解, 溶液化を行う必要がある. この分解操作のとき環境からのコンタミネーションをでき るだけ防ぐため, 密閉型の高圧型反応分解容器（HU-50, 三愛科学製）を用いた．接着剂は高分子化合物であり，一 般的に酸による分解が困難であることから，硝酸を添加し て予備分解を行った上で, 密閉型の分解容器で溶液化する こととした，接着剤で剥離した外樹皮試料の多元素定量分 析の際には, 接着剤の高分子化合物とともに, 外樹皮に付 着した土壤成分に含まれるケイ酸質も完全に分解する必要 があるので, 硝酸とフッ化水素酸を併用が有効である，そ こで，次のような酸分解操作を行った。

試料を PTFE 製小容器に分取し, 濃硝酸 $1 \mathrm{~mL}$ を添加し た後, 室温で 1 晚放置し, 予備分解を行った。この試料入 り PTFE 製小容器を PTFE 製分解容器に入れ, 酸溶液を試 料: 酸 $=1: 30$ (硝酸: 過酸化水素: フッ化水素酸 $=6: 1: 2$ ) の割合（体積比）で, PTFE 製小容器の周りに加えた．直 接試料に混酸溶液を加えないことで, 試薬からのコンタミ ネーションを下げることが期待できる ${ }^{6}$ 。 その PTFE 製分解 容器を耐圧ステンレス製外筒に入れて, 電気炉内で $180^{\circ} \mathrm{C}$ にて 4 時間加熱分解した，その後, PTFE 製小容器内に固 体の残留物がないことを確認し, 分解溶液を PFA 製試験管 に移し，硝酸を添加してアルミバスを用いて蒸発乾固を行 い, フッ化水素酸の除去を行った．フッ化水素酸を直接試 料に添加していないので, 蒸発乾固は 1 回行えば十分であ った，最終的には，分解溶液を $0.1 \mathrm{~mol} \mathrm{~L}^{-1}$ 硝酸で $25 \mathrm{~mL}$ に定容した，更にその一部を希釈し，内標準元素として， $\mathrm{Ge}, \mathrm{In}, \mathrm{Re}$ を各 $10 \mathrm{ng} \mathrm{mL}^{-1}$ になるよう加え, $0.1 \mathrm{~mol} \mathrm{~L}^{-1}$ 硝酸溶液に調製して ICP-MS 測定溶液とした.

この酸分解法及び分析方法の正確さについては, 標準試 料（NIST SRM 1515 Apple Leaves）の粉末を用いて確認し た. 
Table 2 Adhesive used for sampling

\begin{tabular}{cllll}
\hline Sample & \multicolumn{1}{c}{ Brand name } & \multicolumn{1}{c}{ Manufacturer } & \multicolumn{1}{c}{ Type of adhesives $^{14)}$} & \multicolumn{1}{c}{ Constituent } \\
\hline A & ARABIC YAMATO & YAMATO & Water-borne adhesives & polyvinyl alcohol \\
B & Wood-BOND & KONISHI & Emulsion adhesives & polyvinyl acetate \\
C & ARALDITE & Huntsman Advanced Materials & Reactive adhesives & $\begin{array}{l}\text { Base resin : epoxy } \\
\text { Hardener : polyamide amine }\end{array}$ \\
D & High-super 5 & CEMEDINE & Reactive adhesives & Base resin : epoxy \\
& & & & Hardener : polythiol \\
\hline
\end{tabular}

\section{$2 \cdot 5$ 接着剤を用いる樹皮に沈着した重金属元素の採取}

接着剤を塗布し外樹皮を剥離させるためには，樹木の外 樹皮が滑らかな樹皮が望ましい，そこで測定対象とする樹 木には，ケヤキ（Zelkova serrata）を用いた．ケヤキは，本 州, 四国, 九州, 朝鮮半島, 台湾, 中国大陸などに分布し ている樹木であり，街路樹としても様々な場所に植樹され ている.

接着剂を樹木に塗布して外樹皮を採取する位置は，舞い 上がった土ほこりなどの影響を避けるため ${ }^{15)}$ ，人の高さ （約 $1.6 \mathrm{~m} ）$ とした，樹皮の表面に厚さが均一になるように 接着剤を塗布し，接着郕が硬化した後それを剥離させて回 収した，この際，端からゆっくりと剥離させた。 その後, 医療用メスを用いて接着剂の厚みがほぼ均一な中心部から $1 \mathrm{~cm} \times 1 \mathrm{~cm}$ に切り取り, 分析試料とした.

まず隣接する 5 本の樹木から接着剤を使って剥離した樹 皮試料を採取し, 酸分解後 ICP-MS で各元素の定量を行っ た、サンプリングは, 東京理科大学周辺の神楽坂通り（東 京都新宿区神楽坂）で行った。

従来の樹木を用いる重金属污染モニタリングでは，樹皮 そのものを切り取って分析に供する ${ }^{6)}$ １2). 接着郕で最表層 の外樹皮のみを剥離させる本手法で, どのくらい污染物質 を採取することができるか検討をするため, 以下の操作を 行い検討した.

接着剂を外樹皮に塗布し硬化させ，その後，従来法どお り，ただし接着剤と共に樹皮を切り取った。このとき，同 一の樹木から 6 試料を用意した。試料を $1 \mathrm{~cm} \times 1 \mathrm{~cm}$ に切 った後，接着剂を剥離し，剥離した接着剤と残った樹皮 （厚さ約 $1 \mathrm{~mm}$ ）の 2 つに分けて，それぞれ分析に供した。 各元素について, 接着剤で剥離できた割合を式 (1) で算 出した.

$$
\text { Ratio }=\frac{[M]_{\text {resin }}}{[M]_{\text {resin }}+[M]_{\text {bark }}} \times 100
$$

ここで, $[M]_{r e s i n}$ と $[M]_{b a k k}$ は剥離した接着剤中の元素濃 度と残った樹皮中の元素濃度 $\left(\mathrm{ng} \mathrm{cm}^{-2}\right)$ を表す.

\section{2・6 接着剤剥離法を用いた様々な地点における重金属} 污染モニタリング

接着剂による樹皮に沈着した污染物質の採取法を計 6 地 点での大気污染の測定に適用することで地域的な差が見ら れるかどうかを検討した．サンプリング地点は，S1：東京 都新宿区神楽坂（東京理科大学周辺の神楽坂通り）, S2： 東京都板橋区板橋（板橋区役所前：国道 17 号と中山道が 交差し, 首都高速の分岐・合流付近), S3：埼玉県熊谷市 新島（旧中山道の一里塚：樹齢 300 年以上), S4 : 埼玉県 川越市 (住宅街), S5：埼玉県秩父市 (森林地带), S6 : 茨 城県つくば市大穂 (高エネルギー加速器研究機構の構内) の 6 地点とした.

\section{3 結果及び考察}

\section{$3 \cdot 1$ 樹皮沈着污染物質を剥離・回収するための最適な} 接着剤の選択とその多元素定量分析結果

24 種類の接着剂について, 剥離しやすさ, 硬化の迅速性 について検討した結果, アラビックヤマト (ヤマト), 木工 用ボンド (コニシ)，アラルダイト（Huntsman Advanced Materials)，セメダインハイスーパー5 (セメダイン) の接 着剤 4 種が適していた，それぞれの接着剤のタイプと主成 分を併せて Table 2 に示した. これらの 4 種類について, 酸分解を行い, 得られた試料溶液の不純物元素組成につい て ICP-MS による特性化を行った結果を Fig. 1 に示す，縦 軸は，各 $m / z$ における強度を対数軸で表記したものであ る. 対象とする元素名を括弧内に示した.

接着剂によって，含有される不純物には大きな差がある ことが分かる．4種の中では一番不純物が少ないのは，七 メダインハイスーパー 5 (D) であった。この接着片は 2 液 を混合する反応型接着剂であり, 主剤はエポキシ樹脂, 硬 化剂にはポリチオールが用いられている ${ }^{16)}$.このセメダイ ンハイスーパー 5 中の元素濃度を定量した結果を Table 3 に示す. $1 \mathrm{~cm} \times 1 \mathrm{~cm}$ の試料（約 $0.05 \mathrm{~g}$ ）を 10 個作製し, それぞれ分析して得られた平均值と標準偏差及び相対標準 偏差 (RSD) を示し, 各 $m / z$ に打ける元素の検出限界 (analytical detection limit, $\mathrm{ng} \mathrm{g}^{-1}$ ) も併せて示した.

Table 3 に見られるように，接着郕試料において， $\mathrm{Al}$, $\mathrm{Mn}, \mathrm{Ni}, \mathrm{Cu}, \mathrm{Rb}, \mathrm{Sb}, \mathrm{W}, \mathrm{Pb}$ が含まれていたものの $\mathrm{ppb}$ レベルであることが分かった．定量されたすべての元素に 


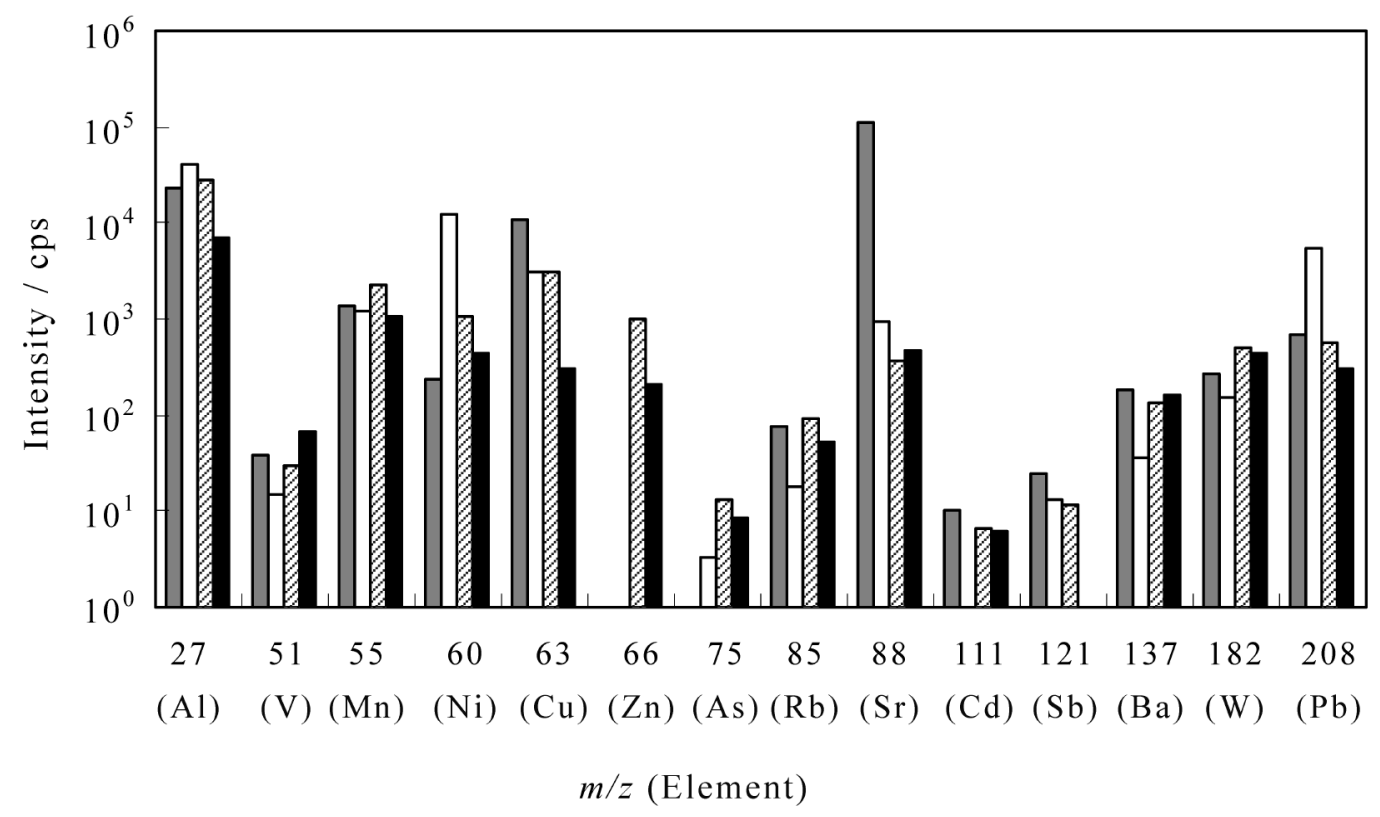

Fig. 1 Trace-component characterization of four adhesives by ICP-MS

$\square$ : sample A ; $\square$ : sample $\mathrm{B}$; $\mathscr{Z Z}$ : sample $\mathrm{C}$; : sample D. Samples A-D were listed in Table 2.

Table 3 Trace-element compositions of the adhesive D analyzed by ICP-MS

\begin{tabular}{|c|c|c|c|c|}
\hline Element & $m / z$ & $\begin{array}{l}\text { Concentration in } \\
\operatorname{resin}^{\text {a) }} / \mathrm{ng} \mathrm{g}^{-1}\end{array}$ & $\mathrm{RSD}^{\mathrm{b})}, \%$ & $\begin{array}{c}\text { Analytical } \\
\text { detection }^{-1} \\
\text { limit }^{c)} / \mathrm{ng} \mathrm{g}^{-1}\end{array}$ \\
\hline $\mathrm{Al}$ & 27 & $674 \pm 103$ & 15 & 92 \\
\hline $\mathrm{V}$ & 51 & $\mathrm{nd}^{\mathrm{d})}$ & - & 5 \\
\hline $\mathrm{Mn}$ & 55 & $54 \pm 13$ & 25 & 26 \\
\hline $\mathrm{Ni}$ & 60 & $359 \pm 81$ & 23 & 26 \\
\hline $\mathrm{Cu}$ & 63 & $347 \pm 99$ & 28 & 28 \\
\hline $\mathrm{Zn}$ & 66 & $\mathrm{nd}^{\mathrm{d})}$ & - & 96 \\
\hline As & 75 & $\mathrm{nd}^{\mathrm{d})}$ & - & 61 \\
\hline $\mathrm{Rb}$ & 85 & $50 \pm 12$ & 23 & 8 \\
\hline $\mathrm{Sr}$ & 88 & nd $^{\text {d) }}$ & - & 10 \\
\hline Cd & 111 & $\mathrm{nd}^{\mathrm{d})}$ & - & 18 \\
\hline $\mathrm{Sb}$ & 121 & $42 \pm 3$ & 6 & 22 \\
\hline $\mathrm{Ba}$ & 137 & nd $^{\text {d) }}$ & - & 69 \\
\hline $\mathrm{W}$ & 182 & $21.7 \pm 4.3$ & 20 & 17 \\
\hline $\mathrm{Pb}$ & 208 & $627 \pm 62$ & 10 & 89 \\
\hline
\end{tabular}

a) Mean \pm standard deviation, $n=10$; b) relative standard deviation ; c) estimated for adhesive sample of $0.05 \mathrm{~g}$; d) not detected. The intensities of ${ }^{27} \mathrm{Al},{ }^{51} \mathrm{~V},{ }^{75} \mathrm{As},{ }^{85} \mathrm{Rb},{ }^{88} \mathrm{Sr}$ were corrected by using the interference correction coefficients of ${ }^{26} \mathrm{Mg}^{1} \mathrm{H},{ }^{35} \mathrm{Cl}^{16} \mathrm{O},{ }^{40} \mathrm{Ar}{ }^{35} \mathrm{Cl},{ }^{48} \mathrm{Ti}^{37} \mathrm{Cl},{ }^{48} \mathrm{Ti}^{40} \mathrm{Ar}$, respectively.

おいて RSD は 6〜28\% であった. Sb は $6 \%$ と比較的小さ い值となったが，その他の元素は，RSD が $10 \%$ 以上とな った。ばらつきが大きくなる原因としては，この接着剤 （セメダインハイスーパー5）が反応型接着剤であるので, 主剤と硬化剤を混合して使用する際に均一性が十分でなか ったことなどが考えられる。これは 2 液混合する接着剤の 欠点といえる。しかしながら, 不純物が少なく, また剥離 しやすさや硬化の迅速性を考慮すると, 今回検討した 24
Table 4 Trace element compositions of the detached adhesive samples, its variation and the blank value of adhesive samples

\begin{tabular}{|c|c|c|c|}
\hline Element & $\begin{array}{l}\text { Detached adhesive } \\
\text { samples }^{\text {a) }} / \mathrm{ng} \mathrm{cm}^{-2}\end{array}$ & $\begin{array}{c}\mathrm{CV}^{\mathrm{b})} \\
\%\end{array}$ & $\begin{array}{c}\text { Blank values for } \\
\text { adhesive }^{\text {c) }} / \mathrm{ng} \mathrm{cm}^{-2}\end{array}$ \\
\hline $\mathrm{Al}$ & 24400 & 20 & 30 \\
\hline V & 60 & 23 & 0.3 \\
\hline $\mathrm{Mn}$ & 2100 & 16 & 3 \\
\hline $\mathrm{Ni}$ & 130 & 23 & 20 \\
\hline $\mathrm{Cu}$ & 650 & 12 & 20 \\
\hline $\mathrm{Zn}$ & 6300 & 20 & $n d^{\text {d) }}$ \\
\hline As & $\mathrm{nd}^{\mathrm{d})}$ & - & nd $^{\text {d) }}$ \\
\hline $\mathrm{Rb}$ & 80 & 16 & 3 \\
\hline $\mathrm{Sr}$ & 300 & 18 & 0.8 \\
\hline $\mathrm{Cd}$ & 6 & 15 & $\mathrm{nd}^{\mathrm{d})}$ \\
\hline $\mathrm{Sb}$ & 40 & 17 & 2 \\
\hline $\mathrm{Ba}$ & 570 & 24 & $\mathrm{nd}^{\mathrm{d})}$ \\
\hline $\mathrm{W}$ & 10 & 23 & 1 \\
\hline $\mathrm{Pb}$ & 790 & 27 & 30 \\
\hline
\end{tabular}

a) Mean value, $n=5$; b) coefficient of variance ; c) analytical results for resin only; $d$ ) not detected

種の接着剂の中では，この接着剂が最適であると考え，以 降の樹皮の剥離に用いた.

\section{$3 \cdot 2$ 接着剂で剥離した樹皮試料の ICP-MS 分析結果}

$3 \cdot 1$ で検討したセメダインハイスーパー 5 を用いて, 隣 接する 5 本の樹木から剥離した樹皮試料の分析結果を Table 4 に示す. ここでは切り取った樹脂 $1 \mathrm{~cm} \times 1 \mathrm{~cm}$ の 単位面積当たりの物質量 $\left(\mathrm{ng} \mathrm{cm}^{-2}\right)$ として表記した. 5 本 から得られた元素濃度の平均值とその変動係数 (coefficient of variance，CV）である．接着剤に含まれる元素濃度 
Table 5 A comparison of trace element compositions of detached adhesive sample with those of the residual bark samples ${ }^{\text {a) }}$

\begin{tabular}{cccc}
\hline Element & $\begin{array}{c}\text { Concentration in detached } \\
\text { adhesive sample } / \mathrm{n} \mathrm{cm}^{-2}\end{array}$ & $\begin{array}{c}\text { Concentration in residual } \\
\text { bark sample }^{\mathrm{b})} / \mathrm{ng} \mathrm{cm}^{-2}\end{array}$ & Detached ratio ${ }^{\mathrm{c})}, \%$ \\
\hline $\mathrm{Al}$ & $25000 \pm 2000$ & $1300 \pm 740$ & $96 \pm 2.3$ \\
$\mathrm{~V}$ & $62 \pm 6.5$ & $7.3 \pm 1.3$ & $91 \pm 0.4$ \\
$\mathrm{Mn}$ & $2200 \pm 150$ & $1800 \pm 330$ & $56 \pm 4.9$ \\
$\mathrm{Cu}$ & $690 \pm 37$ & $550 \pm 68$ & $56 \pm 3.1$ \\
$\mathrm{Zn}$ & $6600 \pm 550$ & $2500 \pm 830$ & $74 \pm 6.8$ \\
$\mathrm{Rb}$ & $81 \pm 5.1$ & $190 \pm 17$ & $31 \pm 1.5$ \\
$\mathrm{Sr}$ & $300 \pm 21$ & $9400 \pm 830$ & $3.2 \pm 0.4$ \\
$\mathrm{Cd}$ & $5.4 \pm 0.4$ & $2.3 \pm 0.6$ & $72 \pm 5.4$ \\
$\mathrm{Sb}$ & $33 \pm 2.9$ & $2.7 \pm 0.7$ & $93 \pm 1.9$ \\
$\mathrm{Ba}$ & $560 \pm 54$ & $2600 \pm 200$ & $18 \pm 1.8$ \\
$\mathrm{~W}$ & $8.1 \pm 1.9$ & $2.3 \pm 0.3$ & $72 \pm 7.5$ \\
$\mathrm{~Pb}$ & $720 \pm 130$ & $140 \pm 11$ & $80 \pm 10$ \\
\hline
\end{tabular}

a) mean \pm standard deviation, $n=6$; b) detached bark sample from adhesive ; c) detached ratio was calculated by the following equation to estimate the amount of elements remained in the bark after sampling by adhesive.

Ratio $=\frac{[M]_{\text {resin }}}{[M]_{\text {bark }}+[M]_{\text {resin }}} \times 100$

$[M]_{\text {rsin }}$ and $[M]_{\text {bark }}$ are the elemental concentrations in the detached resin and the residual bark, respectively.

についても, 同様に $1 \mathrm{~cm} \times 1 \mathrm{~cm}$ の単位面積当たりの物質 量 $\left(\mathrm{ng} \mathrm{cm}^{-2}\right)$ として表記した.

Table 4 に見られるように，本法により樹皮から剥離し た接着剂試料に含まれる $\mathrm{Ni}$ を除くすべての分析対象元素 は，接着剂の不純物レベルよりも十分に濃度が高かった。 $\mathrm{Ni}$ では, 樹皮から剥離した試料中の濃度が $130 \mathrm{ng} \mathrm{cm}^{-2}$ で あるのに対して, 接着剤試料中の濃度は $20 \mathrm{ng} \mathrm{cm}^{-2}$ であ り, 接着剤中の不純物の存在が無視できない. よって, 今 回開発した接着剤で剥離するサンプリング手法は, 樹皮試 料中の $\mathrm{Al}, \mathrm{V}, \mathrm{Mn}, \mathrm{Cu}, \mathrm{Zn}, \mathrm{Rb}, \mathrm{Sr}, \mathrm{Cd}, \mathrm{Sb}, \mathrm{Ba}, \mathrm{W}$, $\mathrm{Pb}$ の定量に有効であるとした.

Table 4 から, 樹皮から剥離した各元素の CV は, 12〜 $27 \%$ となり，ほとんどの元素についてほぼ同じ程度のば らつきであった. 田中らは, 同一地点における環境評価を 行うためのサンプリング条件について検討し ${ }^{9)}$ ，隣接する 10 本の外樹皮をサンプリングしたとき，各元素の CVが 10 〜 40\% であることから, 一地点における特色を得るため には, 樹木 10 本から採取すればよい, としている. 本研究 では, 合成樹脂を用いて隣接する 5 本の樹木から剥離した 試料において, 各元素の CVが $30 \%$ 以下になっていること から, この地点での代表值として取り扱うことができると 考えた．また，Asについては，濃度が非常に低く検出限界 以下であった。

\section{$3 \cdot 3$ 樹皮と接着剤剥離試料の多元素定量分析結果の比較}

樹木を用いて環境污染の評価をするためには, 従来, 樹 皮を切り取り, 分析に供していた. 本研究で検討している 合成樹脂を用いて樹皮を剥離する手法では，表面に沈着し
た物質の回収を目指しているが，従来法と比較してどのく らい有効であるのか検討した結果を Table 5 に示す.

ここでは, 接着剤を塗布してから樹皮を切り取り, そこ から剥離した接着剤試料中の濃度と剥離後に残された厚み $1 \mathrm{~mm}$ 程度の樹皮試料の濃度を示した。また剥離できた割 合を式 (1) で計算し, 同様に Table 5 に示した.いずれも 6 試料における平均値と標準偏差である.

剥離した樹脂において $\mathrm{Al}$ 濃度が高く, またその剥離でき た割合も $96 \%$ と高いことから，これは外部から樹皮に付 着した土壤粒子が起因であると考えられる ${ }^{9)}$. その他, 接 着剤で剥離できた $\mathrm{V}, \mathrm{Zn}, \mathrm{Cd}, \mathrm{Sb}, \mathrm{W}, \mathrm{Pb}$ の割合は 72〜 $93 \%$ である。これらの 6 元素は, 接着剂で剥離した樹皮試 料中に非常に高い割合で存在していることから，樹皮の表 面において存在量が多いといえる.つまり外的要因 (污染) に起因する物質であると考えられる。一方, $\mathrm{Mn}, \mathrm{Cu}, \mathrm{Rb}$, $\mathrm{Sr}, \mathrm{Ba}$ は，接着剤で剥離できた割合は 3〜 56\% と低かっ た.これら 5 元素は, 剥離して残った樹皮試料において濃 度が高いことから，樹皮内に含まれている割合が高い元素 と考えることができる．従来の分析手法では，外樹皮その ものを分析に供しているため, 外的な沈着ではなく植物試 料自体に含まれている元素 $(\mathrm{V}, \mathrm{Mn}, \mathrm{Ni}, \mathrm{Cu}, \mathrm{Zn}, \mathrm{Rb}$, $\mathrm{Sr}, \mathrm{Ba})^{17)}$ と污染物質とを区別することが難しかったが，本 手法を用いれば，外樹皮表面に付着している污染物質を主 に採取することができる，例えば，VはTable 5 に示すよ うに剥離できた割合が $91 \%$ で，またTable 6 において都市 部で有意に高いことから，外因性であることが推定でき る. 
Table 6 Trace-element compositions of bark samples at 6 different points sampled by the present method

\begin{tabular}{|c|c|c|c|c|c|c|c|}
\hline \multirow[t]{3}{*}{ Element } & & \multicolumn{6}{|c|}{ Concentration in the sample $/ \mathrm{ng} \mathrm{cm}^{-2}$} \\
\hline & \multirow{2}{*}{$\begin{array}{c}\text { Sampling } \\
\text { point }\end{array}$} & \multicolumn{2}{|c|}{$\begin{array}{c}\text { Tokyo } \\
\text { Metropolitan }\end{array}$} & \multicolumn{3}{|c|}{$\begin{array}{l}\text { Saitama } \\
\text { Prefecture }\end{array}$} & \multirow{2}{*}{$\begin{array}{c}\begin{array}{c}\text { Ibaraki } \\
\text { Prefecture }\end{array} \\
\text { S6 }\end{array}$} \\
\hline & & S1 & S2 & S3 & S4 & S5 & \\
\hline $\mathrm{Al}$ & & 37900 & 45700 & 72700 & 39800 & 36800 & 33100 \\
\hline V & & 90 & 108 & 122 & 8.4 & 6 & 54 \\
\hline $\mathrm{Mn}$ & & 8000 & 3250 & 1830 & 3740 & 2640 & 1420 \\
\hline $\mathrm{Cu}$ & & 450 & 1120 & 290 & $n d^{\text {a) }}$ & $\mathrm{nd}^{\text {a) }}$ & 130 \\
\hline $\mathrm{Zn}$ & & 1090 & 7050 & 402 & $\mathrm{nd}^{\text {a) }}$ & $\mathrm{nd}^{\text {a) }}$ & 126 \\
\hline $\mathrm{Rb}$ & & 120 & 64 & 75 & 6.8 & 6.8 & 49 \\
\hline $\mathrm{Sr}$ & & 320 & 1340 & 678 & 100 & 148 & 120 \\
\hline $\mathrm{Cd}$ & & 2.8 & 18 & 2.2 & $\mathrm{nd}^{\mathrm{a})}$ & $\mathrm{nd}^{\mathrm{a})}$ & 2.8 \\
\hline $\mathrm{Sb}$ & & 16 & 57 & 11.6 & $\mathrm{nd}^{\text {a) }}$ & $\mathrm{nd}^{\text {a) }}$ & 3.9 \\
\hline $\mathrm{Ba}$ & & 410 & 1350 & 724 & 220 & 293 & 200 \\
\hline W & & 6.3 & 43 & 8.2 & 2.5 & $\mathrm{nd}^{\text {a) }}$ & 1.3 \\
\hline $\mathrm{Pb}$ & & 790 & 1920 & 549 & 268 & 153 & 303 \\
\hline
\end{tabular}

S1 : Kagurazaka Street (Shinjuku); S2 : Itabashi Ward Office (Itabashi); S3 : Old Nakasendo Street (Kumagaya); S4 : Residential area (Kawagoe); S5 : Woodland area (Chichibu); S6 : High Energy Accelerator Research Organization ; KEK (Tsukuba). a) not detected

\section{$3 \cdot 4$ 接着剂剥離法による環境污染評価の検討}

接着剂を用いて，樹皮に沈着している污染物質を剥離回 収することができることが示されたので，実際に接着剂に よる樹皮沈着污染物質の採取法を 6 地点に扔いて行い，地 域的な差が見られるかどうかを検討した。その結果を Table 6 に示した.

今回採取を行った 6 地点の中では, S2 の板橋区役所付近 に扔いて最も交通量が多く，大気污染が進んでいると考え られ，一方，S5 の秩父の試料では森林から採取したため, 污染の少ない地点と考えられる. 実際に S5 では, $\mathrm{Cu}, \mathrm{Zn}$, $\mathrm{Cd} ， \mathrm{Sb}, \mathrm{W}$ は検出限界以下であった。一方，S2 では，例 えば Zn が 7050, Cd が 18, Pbが $1920 \mathrm{ng} \mathrm{cm}^{-2}$ と 6 地点 の中では $\mathrm{Cu}, \mathrm{Zn}, \mathrm{Sr}, \mathrm{Cd}, \mathrm{Sb}, \mathrm{Ba}, \mathrm{W}, \mathrm{Pb}$ の濃度が最も 高く, $\mathrm{V}, \mathrm{Cu}, \mathrm{Zn}, \mathrm{Cd}, \mathrm{Sb}, \mathrm{W}, \mathrm{Pb}$ は S5 の 10 倍以上含 まれていた，このように，Table 5 で剥離される割合が高 い元素 $(\mathrm{V}, \mathrm{Zn}, \mathrm{Cd}, \mathrm{Sb}, \mathrm{W}, \mathrm{Pb})$ では, 地域ごとの違い が大きく現れ，大気污染の指標として本手法が有効である ことが分かった，一方，剥離される割合の低い元素（Mn, $\mathrm{Cu}, \mathrm{Rb}, \mathrm{Sr}, \mathrm{Ba})$ でも, 6 地点に打ける值には違いが見ら れることから，これらの元素でも外部起因（污染）の指標 として使える可能性がある. 過去の研究でも外樹皮の Ba 濃度が大気污染の指標として有効である可能性が示唆され ている ${ }^{11)}$.

また, いずれの地点においても, 各元素の中では $\mathrm{Al}$ 濃度 が最も高い. $\mathrm{Al}$ 濃度は熊谷の試料 $\mathrm{S} 3$ が最も高く, 他の地 点での $\mathrm{Al}$ 濃度はほぼ同じレベルであった. S3 の試料では, 樹齢 300 年の樹木を用いており, この樹龄の違いが外部か ら付着する土壤粒子つまり $\mathrm{Al}$ 濃度に反映されている可能 性はある. 長年, 雨風にさらされていたことから, 長い年
月における $\mathrm{Al}$ の蓄積があり, 更に, 污染物質についてもそ れと同時に多く沈着している傾向が認められた. 他の元素 でも, 検出された元素濃度は, どの程度の大気污染にどの くらいの期間暴露されていたか，ということと関連するた め, 地域間の比較を行うためには, ほぼ同じ樹齢の樹木を 用いることが必要であると考えられる。この地域間の違い を詳細に議論するためには，樹齢の違いを考慮した污染物 質の指標作りが今後必要であるといえる，また，従来法の ように, 樹皮を切り取って分析した定量值と本法の分析值 を比較する際，重金属濃度について単位表記の違いが問題 として挙げられる。樹皮を分析する場合, 重金属濃度は一 般的に樹皮乾燥重量当たりの物質量 $\left(\mathrm{ng} \mathrm{g}^{-1}\right)$ で表記され るが，本法のように外樹皮から樹脂を使って重金属を剥離 する際には，単位面積当たりに塗布する樹脂の量が異なる と, 同じ物質量を剥離しても乾燥重量当たりの重金属濃度 濃度 $\left(\mathrm{ng} \mathrm{g}^{-1}\right)$ は見掛け上ばらついてしまう。そののため, 本 研究では剥離した物質を単位面積当たりの物質量 $\left(\mathrm{ng} \mathrm{cm}^{-2}\right)$ で表記することにした，今後，樹皮に接着片を塗布する際， 単位面積当たりの樹脂量を一定に制御するような工夫をす れば，重量当たりの単位として表記することができるであ ろう。

\section{4 結 論}

現在の環境污染評価を行うための広域・高密度なモニ夕 リング法として，接着剂を用いる樹皮に沈着した重金属污 染物質のサンプリング手法の開発を行った．樹木の地上か ら約 $160 \mathrm{~cm}$ の高さの外樹皮表面に，セメダインハイスー パー 5 を塗布し, 硬化後に剥離した試料を用いて, $\mathrm{Al}, \mathrm{Sb}$, $\mathrm{V}, \mathrm{Pb}, \mathrm{Zn}, \mathrm{Cd}, \mathrm{W}, \mathrm{Mn}, \mathrm{Cu}, \mathrm{Rb}, \mathrm{Ba}, \mathrm{Sr}$ に関する環境 
污染評価ができることが分かった．樹皮表面に付着してい る污染物質は接着剤により効率的に回収できた。 6 地点に おける環境污染評価を行ったところ，この接着剤剥離法に より，それぞれの地点における污染の特色を得ることがで きた，本手法は樹木に与えるダメージが少なく，迅速・簡 便な採取法であることから, 今後は様々な地域における污 染評価へ適用することが期待される.

\section{文献}

1) P. Little, M. H. Martin : Environ. Pollut., 6, 1 (1974).

2) E. Neiboer, H. M. Ahmed, K. J. Puckett, D. H. S. Richardson : Lichenologist, 5, 292 (1972).

3) K. Pilegaard : Environ. Pollut., 17, 81 (1978).

4) Å. Ruhling, G. Tyler : Water, Air \& Soil Pollut., 2, 445 (1973).

5) J. Sheline, R. Akselsson, J. W. Winchester : J. Geophys. Res., 81, 1047 (1976).

6) D. Bellis, A. J. Cox, I. Staton, C. W. McLeod, K. Satake : J. Environ. Monit., 3, 512 (2001).

7) D. Bellis, R. Ma, N. Bramall, C. W. McLeod : Sci. Total Environ., 264, 283 (2001).
8) J. S. Becker, D. Bellis, I. Staton, C. W. McLeod, J. Dombovari, J. S. Becker : Fresenius J. Anal. Chem., 368, 490 (2000).

9) J. Tanaka, M. Ichikuni : Atmos. Environ., 16, 2015 (1982).

10) N. I. Ward, R. R. Brooks, R. D. Reeves : Environ. Pollut., 6, 149 (1974).

11) S. R. Oliva, M. D. Mingorance : Chemosphere, 65, 177 (2006).

12) E. Schelle, B. G. Rawlins, R. M. Lark, R. Webster, I. Staton, C. W. McLeod : Environ. Pollut., 155, 164 (2008).

13) A. Hokura, H. Matsuura, F. Katsuki, H. Haraguchi : Anal. Sci., 16, 1161 (2000).

14) JIS K 6800, 接着剤・接着用語 (1985).

15) 浮遊粒子状物質対策検討会著, 環境庁大気保全局大 気規制課監修: “浮遊粒子状物質污染予測マニュア ル”, (1997), (東洋館出版社).

16) セメダイン(株) MSDS 検索＜http://www.cemedine. co.jp/msds/index.html $>$.

17) 高井康雄, 早瀬達郎：“植物栄養土壌肥料大辞典”, (1987), (養賢堂).

18) 岩井和郎: 大気環境学会誌, 32, 323 (1997).

\title{
Development of a New Sampling Method Using Synthetic Resin Adhesive for Environmental Monitoring of Heavy-Metal Deposits on Tree Bark
}

\author{
Akiko HokURA $^{1,3}$, Hajime ChibA ${ }^{1}$, Ken-ichi SATAKE ${ }^{2}$ and Izumi NAKaI ${ }^{1}$
}

\footnotetext{
${ }^{1}$ Department of Applied Chemistry, Faculty of Science, Tokyo University of Science, 1-3, Kagurazaka, Shinjuku-ku, Tokyo 162-8601

${ }^{2}$ Department of Environment Systems, Faculty of Geo-Environmental Science, Rissho University, 1700, Magechi, Kumagaya-shi, Saitama 360-0194

${ }^{3}$ Present address, Waseda Institute for Advanced Study (WIAS), Waseda University, 1-6-1, Nishi-waseda, Shinjuku-ku, Tokyo 169-8050
}

(Received 19 November 2008, Accepted 18 February 2009)

A method for specimen collection by using a synthetic resin adhesive is proposed as a new sampling method for monitoring of heavy-metal deposits on tree bark. The resin adhesive was applied to tree bark of Zelkova serrata (Keyaki in Japanese name) at $160 \mathrm{~cm}$ high from the ground. An adhesive sample was peeled from the bark after hardening, and subjected to ICP-MS analysis. It was found that $\mathrm{V}, \mathrm{Zn}, \mathrm{Cd}, \mathrm{Sb}, \mathrm{W}, \mathrm{Pb}$ were efficiently collected by the resin from the bark. This sampling method was applied to the monitoring of heavy-metal pollution at 6 points, including urban, suburban, and rustic region of the Kanto region of Japan. The concentrations of $\mathrm{V}, \mathrm{Cu}, \mathrm{Zn}, \mathrm{Cd}, \mathrm{Sb}, \mathrm{W}$ and $\mathrm{Pb}$ in the samples at an urban site were more than 10-times higher (e.g. Pb $1920 \mathrm{ng} \mathrm{cm}^{-2}$ ) than those at a rural site (e.g. Pb $153 \mathrm{ng} \mathrm{cm}^{-2}$ ). This sampling method is simple, quick and causes less damage to the trees against sampling. Consequently, it will be useful for widespread and high-density environmental monitoring of heavy-metal pollutants.

Keywords : tree bark; resin adhesive ; ICP-MS ; heavy metal ; sampling method. 